\title{
Effect of Nitrogen Levels and Foliar Application of Potassium Sulfate and Micronutrients on Growth and Yield of Maize Preceded By Wheat or Clover
}

\author{
EL-Metwally, A. EL-M. ${ }^{1}$; S.A.Safina ${ }^{1}$, F.E. Abdalla ${ }^{2}$; Khalifa, R. Kh. M. ${ }^{2}$ and Sara. S. EI-Sawy ${ }^{2}$ \\ 1. Agronomy Dept., Fac.Agric., Cairo University, Giza, Egypt \\ ${ }^{2}$. Fertilization Technology Dept., National Research Centre (NRC), Giza, Egypt \\ Corresponding author: Sara.agric@yahoo.com
}

\begin{abstract}
Intensive crop rotation and imbalance fertilizer use have resulted in a wide range of nutrients deficiency in fields. For intensive cropping systems, the current recommended fertilizers rates need revision upwards with in balance ratio of vital micronutrients specific to crop to enhance stagnant yields. Two field experiments were carried out at the Agric. Exp. Sta., Fac. Agric., Cairo University, Egypt during 2014/2015 and 2016/2017 seasons to study the effect of preceding winter crops (Wheat or Egyptian clover), nitrogen levels (90, 120 and $150 \mathrm{~kg}$ $\mathrm{N} /$ fed.) and foliar minerals application (Control, potassium sulphate and micronutrient compound of high zinc as well as their interaction) on growth and yield of Zea mays L. cv. single cross 131. The experimental design was split- split plot design with three replications. Results showed that maize planted after Egyptian clover provided the highest grain yield per plant (201.1 and 250.4 g), grain yield per fed. (3.474and3.487 ton) as well as harvest index $(0.35$ and $0.25 \%)$ as compared to maize sown after wheat for both seasons, respectively. Increasing $\mathrm{N}$ rates from 90 to $120 \mathrm{~kg} /$ fed.and from 120 to $150 \mathrm{~kg} /$ fed.increased grain yield/plant by about $5.2 \%$ and $1.9 \%$ in the $1^{\text {st }}$ season, corresponding to $2.9 \%$ and $1.9 \%$ in the $2^{\text {nd }}$ season, respectively. Increasing $\mathrm{N}$ rates from 90 to 120 $\mathrm{kg} / \mathrm{fed}$.and from 120 to $150 \mathrm{~kg} / \mathrm{fed}$ increased grain yield/fed by about $24.6 \%$ and $12.8 \%$ in the $1^{\text {st }}$ season, corresponding to $25.9 \%$ and $12.1 \%$ in the $2^{\text {nd }}$ season, respectively. Maize plants grown after Egyptian clover and receiving $150 \mathrm{~kg} \mathrm{~N} /$ fed.with the applied micronutrients and $\mathrm{k}$ foliar spray gave the highest grain yield/fed. (4.083 and 4.139 ton)in both seasons. The lowest value of grain yield/fed.was shown when maize was grown after wheat and receiving $90 \mathrm{~kg} \mathrm{~N} / \mathrm{fed}$.with foliar application of micronutrients and k sulfate in both seasons. Maize grown after Egyptian clover and receiving $120 \mathrm{~kg} \mathrm{~N} /$ fed.and foliar application of micronutrients and $\mathrm{k}$ sulfate is recommended for maize production. On the other hand, maize grown after wheat with application of $150 \mathrm{~kg} \mathrm{~N} / \mathrm{fed}$ and foliar application of micronutrients and $\mathrm{k}$ sulfate is recommended for maize production. Regression analysis reveal the relation between the two variables, i. e., preceding crops (x) and Grain yield/fed (y) there was a linear relation, and, highly significant $(\mathrm{P} \leq 0.01)$ correlation coefficient $(\mathrm{r}=1)$ during the first and second seasons. Linear regression equation for $\mathrm{N}$ rates suggested that increase in one unit (30 kg/fed.) led to increase grain yield/fed.by 0.35 ton/fed.during the first and second seasons.
\end{abstract}

Keywords: Corn, Zea maize L, Nitrogen rates, Potassium, Micronutrients, Foliar application, Growth and yield.

\section{Introduction}

Maize is one of the high noteworthy crops due to its importance in nutrition of livestock and poultry overall the world. In Egypt maize (Zea mays L.) is the third most important staple food crop in terms of area and production after wheat and rice. Total area under cultivation of maize in Egypt is 888329 ha about 25.17 $\%$ of the total cultivated agricultural land while average yield is 7.80 ton ha ${ }^{-1}$. Maize is about $21.90 \%$ of the total cereals production (FAO, 2016).

Improving maize productivity has been a major goal for maize researchers in Egypt. The Egyptian government aims to decrease the gap between consumption and production by increasing grain yield per unit area of the agricultural land. There are several approaches to increase crop productivity among of them: improving farming practices, employing merging technology, using modern and high yielding maize hybrids which are more efficiently for using nitrogen and more response to high rate of nitrogenous fertilizer to achieve high grain yield.
Varvel and Peterson (1990) stated that crop rotation reduced inorganic nitrogen fertilizer needs and at the same time reduced the available of nitrogen from leaching, both of which were important for increasing crop yields. Many investigators showed that winter legumes are the ideal preceding crops for maize. Bader, 1999; Shams, 2000; Khalil et al., 2001; El-Douby, 2002 and Toaima and Saleh, 2003 showed that wheat as preceding crop stimulated maize to be more responsive to utilize $\mathrm{N}$ applied as compared to legume as preceding crops. El-Gizawy (2009) demonstrated that sowing maize after faba bean gave the highest values of grain yield and its components.

Egyptian soils are known to be poor in available nitrogen due to their low content of organic matter and the small amounts of organic manures added annually. Nitrogenous fertilizers are one of the most important factors for crop growth, high yield and yield components. Where, nitrogen plays an essential role in many compounds essential for plant growth, chlorophyll and many enzymes. It is considered the key element in increasing crops productivity, also, 
helps in the use of $\mathrm{P}, \mathrm{K}$ and other elements in plants. Nitrogen is vital in crop productivity which plays a role in accelerating yield and gave optimum economic return. Its deficiency will constitutes in low yield and productivity in cereal crops. Excessive $\mathrm{N}$ fertilization may result in low nitrogen use efficiency (NUE) and potentially exerts more pressure on the environment. Efficient nitrogen use by maize permits use of appropriate source in an adequate amount, at proper timing and suitable application rates. The positive effects of $\mathrm{N}$ application on growth and yield of maize were demonstrated by several investigations. ElGizawy (2009) at Moshtohor, Kalubia Gov., Egypt in clay soil found that growth, yield of maize and yield components significantly increased with increasing the rate of $\mathrm{N}$ fertilizer up to $120 \mathrm{~kg} \mathrm{~N} /$ fed. Onasanya et al. (2009) in southern Nigeria in sandy loam soil showed that application of $120 \mathrm{~kg} \mathrm{~N} / \mathrm{ha}$. significantly increased the growth of maize. Wasaya (2011) at Faisalabad, Pakistan in sandy clay loam soil reported that increasing nitrogen application rate had positive impact on growth, yield component sand yield. Maize yield with $200 \mathrm{~kg} \mathrm{ha}^{-1}$ nitrogen application was $17 \%$ and $8.50 \%$ higher than 100 and $150 \mathrm{~kg} \mathrm{ha}^{-1}$ nitrogen application respectively. Dawadi and Sah (2012) in Nebal in sandy loam soil indicated that increasing nitrogen levels from $120 \mathrm{~kg} \mathrm{ha}^{-1}$ to $200 \mathrm{~kg} \mathrm{ha}^{-1}$ enhanced the plant height, grain yield and stover yield of hybrid maize whereas, increasing nitrogen levels decreased harvest index and grain / stover ratio.

Khan et al. (2012) in Peshawar, Pakistan showed that increase of nitrogen levels enhanced final seed yield due to increase of seed number in each ear. Also, nitrogen levels were significantly affected the maize plant height. The tallest plants were recorded under 120 and $150 \mathrm{~kg} \mathrm{~N} \mathrm{ha}^{-1}$ and the greatest grain yield of maize (1.5 ton ha-1) was found under the $160 \mathrm{~kg} \mathrm{~N}^{-1}$ 1. Kandil (2013) at Alexandria University, in clay loamy soil found that the maximum plant height, leaf area index (LAI), harvest index and protein content were produced by the application either 429 or $357 \mathrm{~kg}$ $\mathrm{N}$ ha ${ }^{-1}$. Wei et al. (2016) at Shandong, China in sandy loam soil observed that, the rate of photosynthesis decreased significantly under $\mathrm{N}$ deficiency and this response was associated with leaf senescence.

Potassium interacts with most of the essential macronutrients, secondary nutrients, and micronutrients. Aslam et al. (2013) reported that potassium application enhanced root growth and stem elongation. Similarly, potassium increased leaf water potential, osmotic potential and turgor potential under drought stress. Application of potassium enhanced the photosynthetic rate and has better effect on other attributes. Potassium enhanced the yield and yield related parameters of maize crop.

Micronutrients are required in small amounts and they affect directly or indirectly photosynthesis, vital processes in plant such as respiration, protein synthesis, reproduction phase (Marschner, 1995). ElAkabawy et al. (2001) stated that the beneficial effects of micronutrients application were recorded by many workers on soils of Egypt. Salem and El-Gizawy (2012) reported that micronutrient fertilization using $\mathrm{Zn}+\mathrm{Mn}+\mathrm{Fe}$ treatment was the most effective treatment in all studied maize traits. Foliar spraying gave the highest values of ears/plant, grains/ear, 100grain weight and grain yield in both seasons.

Manganese has an essential role in amino acid synthesis by activating a number of enzymes particularly, decarboxylases and dehydrogenases of the tricarboxylic acid cycle (Marschner, 1995). ElGizawy (2000) found that the highest grain yield was recorded by foliar application or grain soaking with $\mathrm{Mn}$. Iron is a constituent of many enzymes involved in the nutritional metabolism of plant (Marschner, 1995 and Kabata-Pendiasand Pendias, 1999). Zinc plays an important role as a metal component of enzymes (superoxide dismutase, carbonic anhydrase and RNA polymerase) or as a functional, structural, or regulator cofactor of a large number of enzymes (Marschner, 1995 and Kabata-Pendias and Pendias, 1999). Rego et al. (2007) reported an increase in grain yield of maize by $\mathrm{Zn}$ application was achieved.

The present study aimed to identify the nitrogen fertilizer requirements as a soil application as well as potassium sulfate and micronutrient compound as foliar application on growth and grain yield of maize preceded by wheat or Egyptian clover.

\section{Materials and Methods}

Two field experiments were carried out at Agric. Res. Exp. Sta. Giza, Fac. Agric., Cairo University, Egypt. The aim was to assess the effect of $\mathrm{N}$ rates and foliar application of micronutrients and $\mathrm{K}$ sulfate on growth and grain yield of maize grown after wheat or Egyptian clover. Physical and chemical properties of the soil were determined according to the standard procedures described by Black (1965). The mechanical and chemical analysis characteristics of the experimental soil at $30 \mathrm{~cm}$ depth before sowing winter crops and maize in 2015 and 2017 seasons are shown in table1.

Each experiment included 24 treatments which were the combination of two preceding crops (wheat or Egyptian clover), three $\mathrm{N}$ rates (90, 120 and $150 \mathrm{~kg}$ $\mathrm{N} /$ fed) and four foliar applications for $\mathrm{K}$ sulfate and micro-nutrient compound (Control,1g/l micronutrients compound high in its zinc content $(\mathrm{Fe}$ $1.5 \%$, Mn $1.5 \%$, and $\mathrm{Zn} 4.5 \%$ ), K sulphat (1\%) and Micro $+\mathrm{K})$. The experimental design was splitsplit plot based on randomized complete block design with three replications. The studied two preceding crops which considered as the main factor. Nitrogen rates as subplots and foliar application for $\mathrm{K}$ and micronutrients compound as sub-sub plots. Plot size was $14 \mathrm{~m}^{2}$ having 5 ridges of $4 \mathrm{~m}$ in length and $0.7 \mathrm{~m}$ in width. 
Table 1. Physical and Chemical characteristics of the experimental soil (30 $\mathrm{cm} \mathrm{depth)} \mathrm{before} \mathrm{sowing} \mathrm{winter} \mathrm{crops}$ and maize in both seasons.

\begin{tabular}{|c|c|c|c|c|c|}
\hline \multirow{3}{*}{ Parameter } & \multirow{3}{*}{$\begin{array}{l}\text { Before } \\
\text { Winter } \\
\text { crops }\end{array}$} & \multicolumn{4}{|c|}{ Before sowing maize } \\
\hline & & $\begin{array}{l}\text { After } \\
\text { wheat }\end{array}$ & $\begin{array}{l}\text { After } \\
\text { clover }\end{array}$ & After wheat & $\begin{array}{l}\text { After } \\
\text { clover }\end{array}$ \\
\hline & & \multicolumn{2}{|c|}{2015 season } & \multicolumn{2}{|c|}{2017 season } \\
\hline \multicolumn{6}{|c|}{ Physical characteristics } \\
\hline Cors sand ( \%) & 3.88 & 3.72 & 3.73 & 3.72 & 3.73 \\
\hline Fine sand $(\%)$ & 31.42 & 31.44 & 31.45 & 31.44 & 31.42 \\
\hline Silt $(\%)$ & 29.11 & 29.20 & 29.21 & 29.20 & 29.19 \\
\hline Clay ( \%) & 35.59 & 35.64 & 35.65 & 35.64 & 35.66 \\
\hline Texture & Clay loam & Clay loam & Clay loam & Clay loam & Clay loam \\
\hline \multicolumn{6}{|c|}{ Chemical characteristics } \\
\hline E.C. dS/m & 0.64 & 0.21 & 0.13 & 0.53 & 0.49 \\
\hline pH & 8.36 & 8.96 & 8.37 & 7.95 & 7.85 \\
\hline $\mathrm{CaCO}_{3}(\%)$ & 3.60 & 5.20 & 4.40 & 6.80 & 6.80 \\
\hline Organic matter (\%) & 1.78 & 1.89 & 2.56 & 2.04 & 2.69 \\
\hline \multicolumn{6}{|c|}{ Macronutrients (mg/100g soil) } \\
\hline $\mathbf{P}$ & 1.05 & 1.10 & 1.66 & 1.15 & 1.84 \\
\hline $\mathbf{K}$ & 23.00 & 26.00 & 36.40 & 32.00 & 44.4 \\
\hline $\mathbf{N a}$ & 32.00 & 36.00 & 52.40 & 73.00 & 78.00 \\
\hline $\mathbf{C a}$ & 480.0 & 527.0 & 598.0 & 630.0 & 782.0 \\
\hline Mg & 110.0 & 112.0 & 184.0 & 120.0 & 200.0 \\
\hline \multicolumn{6}{|l|}{ Micronutrients (ppm) } \\
\hline $\mathbf{F e}$ & 5.30 & 12.30 & 14.00 & 12.50 & 15.2 \\
\hline Mn & 1.50 & 1.00 & 1.44 & 1.48 & 2.10 \\
\hline $\mathbf{Z n}$ & 1.00 & 1.11 & 1.38 & 2.80 & 3.80 \\
\hline $\mathrm{Cu}$ & 1.00 & 1.22 & 1.32 & 2.60 & 3.20 \\
\hline
\end{tabular}

Maize cv. S.C.131 (developed by Maize Res.Sec. Agric. Res. Center, Giza, Egypt) was sown on $1^{\text {th }}$ May in 2015 and 2017 growing seasons. Two maize kernels were hand sown in hills spaced $25 \mathrm{cmon}$ ridges spaced $70 \mathrm{~cm}$. Phosphorus fertilizer was applied before planting at the rate of $150 \mathrm{kgcalcium}$ super phosphate $\left(15.5 \% \mathrm{P}_{2} \mathrm{O}_{5}\right) /$ fed. Plots were hand-thinned at the $\mathrm{V}_{3}-\mathrm{V}_{4}$ leaf stage (before the $1^{\text {st }}$ irrigation) to one plant per hill. Ammonium nitrate $\left(\mathrm{NH}_{4} \mathrm{NO}_{3} 33.5 \mathrm{~N} \%\right)$ was applied as the nitrogen source in both seasons, which was applied in two equal doses, at the $\mathrm{V}_{3}-\mathrm{V}_{4}$ and at $\mathrm{V}_{5}-\mathrm{V}_{6}$ leaf stage (before the $1^{\text {st }}$ and $2^{\text {nd }}$ irrigations). Potassium fertilizer in the form of potassium sulphate with rate $1 \%$ applied as foliar application, micronutrient compound high in zinc was applied as foliar application with rate at $1 \mathrm{~g} /$ liter (Fe $1.5 \%, \mathrm{Mn} 1.5 \%$, and $\mathrm{Zn} 4.5 \%$ ) two times at 45 and 60 day after sowing. The plots were hand hoed twice for controlling weeds before the first and second irrigations.

\section{The studied traits:}

1- Growth characteristics: After 75 days from planting five random maize plants were taken from each plot to determine total dry weight/plant. Average length and width was calculated for each plant and then multiple with the maize correction factor of 0.75 to find out the leaf area/plant. Leaf area index (LAI) was calculated by the formula: $\mathrm{LAI}=$ Leaf area/ Land area.
2- Yield parameters: At harvest, plant height and grain yield/plant were recorded on ten guarded plants from each plot. Grain yield ton/feddan was calculated by weighting grain yield $(\mathrm{Kg})$ from the whole area of each experimental unit (sub-plot, each sub-plot consists of 4 ridges) and then adjusted into ton per fed. The grain yield ton/fed. was adjusted on the basis of $15.5 \%$ grain moisture content. Harvest index (H.I. \%): H.I. = Economic yield/biological yield $\times 100$ according to Clipson et al. (1994).

\section{Statistical analysis}

Data were statistically analyzed according to Gomez and Gomez (1983) using the MSTAT-C Statistical Software Package (Freed, 1991) and for drawing the diagrams,

Excel software was used. Where the F-test showed significant differences among means, least significant differences (LSD) test was performed at the 0.05 level of probability to separate means.

\section{Results and Discussion}

Some agronomic traits of maize as affected by previous crop (wheat or Egyptian clover)

Data presented in Table 2 showed the effects of preceding winter crops on total dry weight, LAI, plant height, grain yield/plant, grain yield/fed and harvest index. Results clearly showed that total dry weight, LAI and plant height of maize preceded by Egyptian 
clover were higher by (59.5 and $24.1 \%$ ), ( 9.8 and $4.4 \%$ ) and ( 2.2 and $2.0 \%$ ) than those of maize plants preceded by wheat in both seasons, respectively. Planted maize sowed after Egyptian clover gave the highest grain yield per plant (201.1 and $250.4 \mathrm{~g}$ ), grain yield per fed. (3.474and3.487 ton) as well as harvest index $(0.35$ and $0.25 \%)$ than maize sowed after wheat for both seasons, respectively (Table 2 and Fig.1). These increases correspond to (10.3 and 7.9\%) for grain yield/plant and (14.4 and $13.3 \%)$ for grains yield/fed. in the first and second seasons, respectively.
(Table 1)These results could be attributed to the effect of Egyptian clover as a legume forage crop in enriching the soil with $\mathrm{N}$, organic matter residue which improve the physical, chemical and biological characteristics of the soil and then induced better growth of the following maize. These results are in agreement with those obtained by Shams (2000), Abd El-All (2002) and El-Gizawy (2009) who found that maize grown after legume crops gave higher yield than after cereal crops.

Table 2. Effect of preceding crop, $\mathrm{N}$ rate and foliar application of micronutrients and $\mathrm{K}$ sulfate on some growth, yield and harvest index traits of maize in 2015 and 2017 seasons.

\begin{tabular}{|c|c|c|c|c|c|c|c|c|c|c|c|c|}
\hline \multirow[t]{2}{*}{ Treatment } & \multicolumn{2}{|c|}{$\begin{array}{c}\text { Total dry } \\
\text { weight/plant } \\
\text { (g) }\end{array}$} & \multicolumn{2}{|c|}{$\begin{array}{l}\text { Leaf area } \\
\text { index }\end{array}$} & \multicolumn{2}{|c|}{$\begin{array}{c}\text { Plant } \\
\text { height (cm) }\end{array}$} & \multicolumn{2}{|c|}{$\begin{array}{c}\text { Grain } \\
\text { yield/plant } \\
\text { (g) }\end{array}$} & \multicolumn{2}{|c|}{$\begin{array}{l}\text { Grain yield } \\
\text { (ton/fed.) }\end{array}$} & \multicolumn{2}{|c|}{$\begin{array}{l}\text { Harvest } \\
\text { index }\end{array}$} \\
\hline & 2015 & 2017 & 2015 & 2017 & 2015 & 2017 & 2015 & 2017 & 2015 & 2017 & 2015 & 2017 \\
\hline \multicolumn{13}{|l|}{ Preceding crop } \\
\hline Wheat & 589.4 & 880.5 & 5.1 & 6.8 & 216.0 & 230.3 & 182.3 & 232.0 & 3.038 & 3.078 & 0.30 & 0.26 \\
\hline Egyptian clover & 940.3 & 1092.4 & 5.6 & 7.1 & 220.7 & 234.9 & 201.1 & 250.4 & 3.474 & 3.487 & 0.35 & 0.25 \\
\hline F test & $* *$ & $* *$ & $*$ & $* *$ & $*$ & $* *$ & $* *$ & $* *$ & $* *$ & $* *$ & $* *$ & $*$ \\
\hline \multicolumn{13}{|l|}{$\mathrm{N}$ rates $\mathrm{kg} / \mathrm{fed}$} \\
\hline 90 & 632.7 & 944.4 & 5.2 & 6.9 & 214.9 & 231.9 & 184.3 & 228.8 & 2.676 & 2.684 & 0.32 & 0.25 \\
\hline 120 & 766.7 & 1040.9 & 5.3 & 7.0 & 220.5 & 233.0 & 194.9 & 240.8 & 3.333 & 3.378 & 0.33 & 0.25 \\
\hline 150 & 895.2 & 974.0 & 5.4 & 7.0 & 219.6 & 232.8 & 195.9 & 254.1 & 3.759 & 3.786 & 0.33 & 0.26 \\
\hline LSD 5\% & 14.7 & 25.1 & ns & ns & ns & ns & 2.6 & 4.8 & 0.047 & 0.056 & ns & ns \\
\hline \multicolumn{13}{|c|}{ Foliar Application } \\
\hline Control & 421.7 & 943.2 & 4.1 & 6.4 & 197.2 & 226.5 & 141.1 & 224.2 & 3.149 & 3.180 & 0.30 & 0.28 \\
\hline Micronutrients & 823.1 & 1025.0 & 5.6 & 7.0 & 225.9 & 233.2 & 208.9 & 244.8 & 3.223 & 3.243 & 0.33 & 0.26 \\
\hline K sulfate & 890.5 & 978.9 & 5.7 & 7.1 & 224.8 & 236.2 & 206.7 & 244.9 & 3.287 & 3.305 & 0.33 & 0.24 \\
\hline Micro + K & 924.1 & 998.6 & 5.9 & 7.2 & 225.4 & 234.5 & 210.0 & 251.0 & 3.364 & 3.404 & 0.34 & 0.24 \\
\hline LSD 5\% & 20.5 & 36.1 & 0.2 & 0.2 & 1.9 & 1.4 & 2.7 & 4.2 & 0.071 & 0.064 & 0.01 & 0.02 \\
\hline
\end{tabular}

*, ** significantly different at 0.05 and 0.01 probability levels, respectively, ns: not significant.

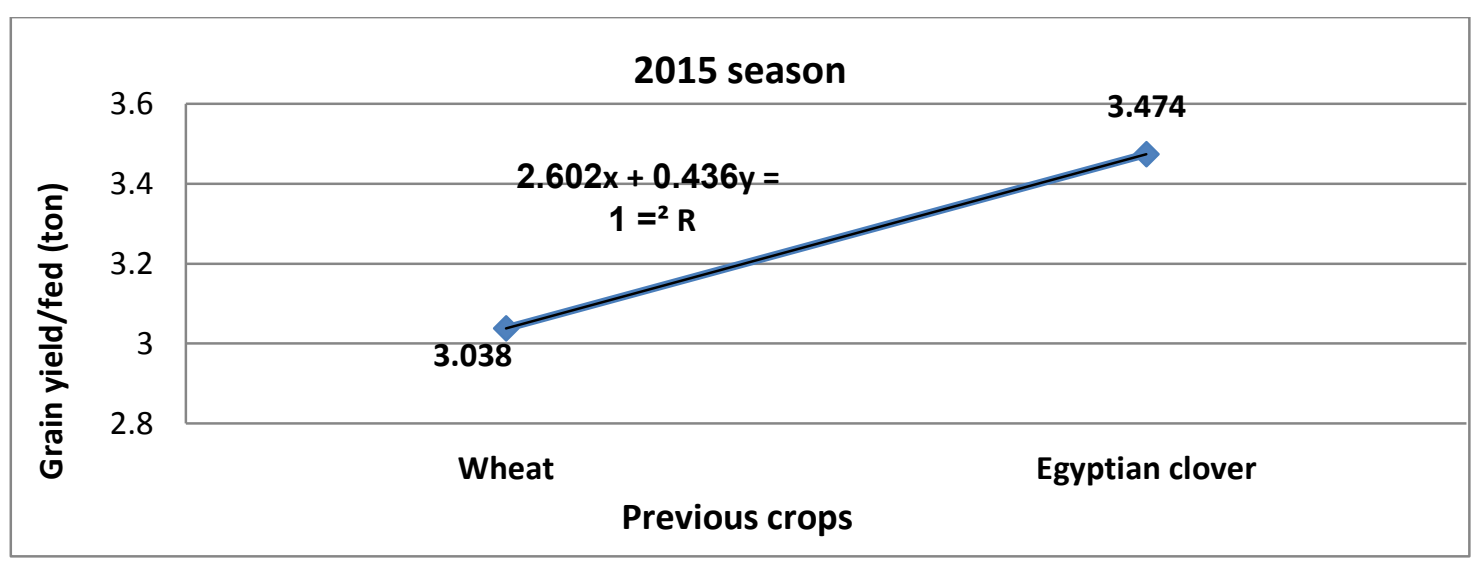




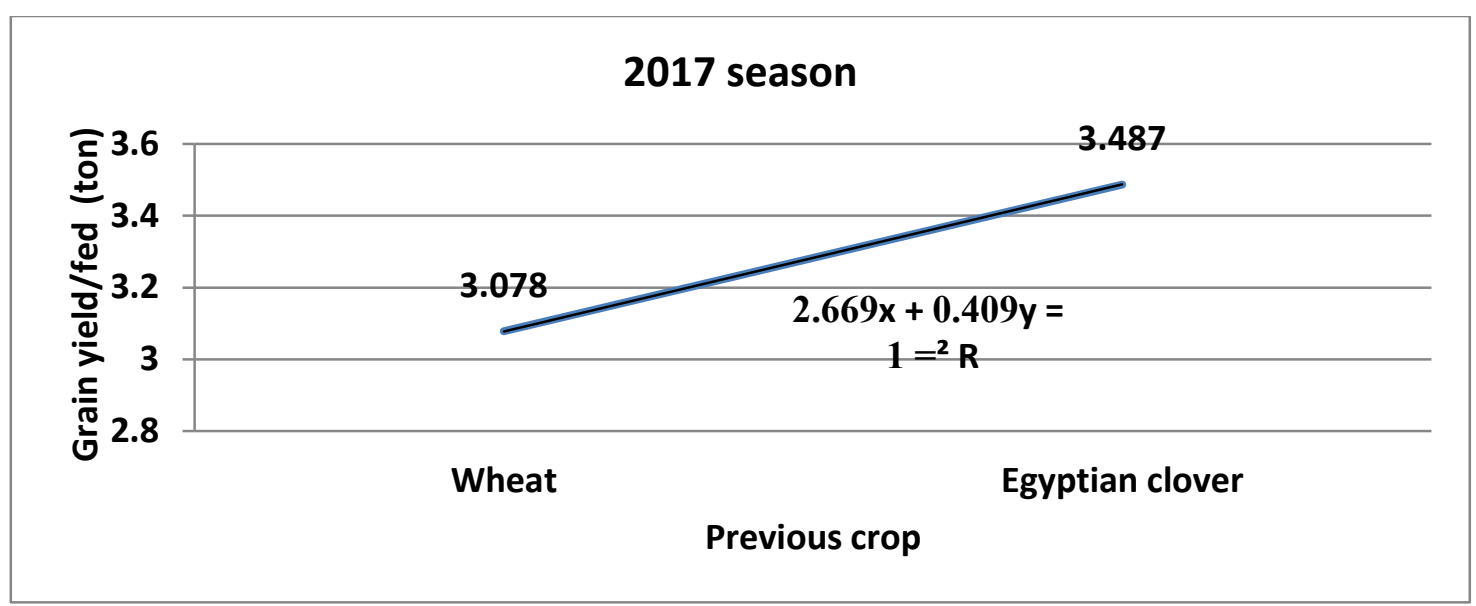

Fig.1. Relationships between wheat and Egyptian clover as a preceding winter crops and maize grain yield/fed. in 2015 and 2017 seasons.

Regression analysis reveal the relation between the two variables, i. e., preceding crops (x) and grain yield/fed(y) there was a linear relation and highly significant $(\mathrm{P} \leq 0.01)$ correlation coefficient $(\mathrm{r}=1)$ during the first and second seasons (Fig.1). Besides, $\mathrm{R}^{2}$ (coefficient of determination) revealed that it was possible to account up to $1 \%$ of the variability in yield of grain yield/fed (y), to preceding crops during the first and second seasons. The relationship between preceding crops and grain yield/fed. was positive and followed the linear equation: of $Y=2.602+0.436 x$ and $\mathrm{Y}=2.669+0.409 \mathrm{x}$, representing a positive value of $(\mathrm{b})$, during the first and second seasons, resp., which means yield increase against when maize planted after Egyptian clover.

Effect of nitrogen rate on some growth and yield traits of maize preceded in winter by wheat or Egyptian clover

Data presented in table 2 showed the effect of $\mathrm{N}$ rates added to maize on total dry weight, grain yield/plant and grain yield/fed. of maize cv. Single cross 131 in 2015 and 2017 seasons. Results revealed that $\mathrm{N}$ rates resulted in significant positive effect on total dry weight; grain yield/plant and grain yield/fed. in both seasons. While, $\mathrm{N}$ rates showed insignificant effect on LAI, plant height and harvest index in both seasons. In the first season, increasing $\mathrm{N}$ rate from 90 to 120 and 150 resulted in significant increment in the total dry weight, while in the second season the highest increment in total dry weight was obtained by increasing $\mathrm{N}$ rate only up to $120 \mathrm{~kg} / \mathrm{fed}$. The increment amounted to $21.2 \%$ and $14.5 \%$ in the first season as $\mathrm{N}$ rate increased from 90 to $150 \mathrm{~kg} / \mathrm{fed}$., respectively. While the highest increment in total dry weight reached to only $10.2 \%$ in the second season by increasing $\mathrm{N}$ rate from 90 to $120 \mathrm{~kg} / \mathrm{fed}$. This increase in total dry weight/plant is mainly due to the role of $\mathrm{N}$ in stimulating the meristematic growth activity which contributes to the increase in number of cells in additions to cell enlargement. Similar findings were reported by El-Gizawy (2009), Onasanya et al. (2009), Wasaya (2011) and Dawadi and Sah (2012).
Concerning grain yield/plant, data showed that increasing $\mathrm{N}$ rates from 90 to 120 and from 120 to 150 $\mathrm{kg} / \mathrm{fed}$. Significantly increased grain yield/plant by about $5.8 \%$ and $0.5 \%$ in the first season, and by 5.2 and $5.5 \%$ in the second season. The increase in grain yield/plant accompanying high $\mathrm{N}$ rate might have been due to the increase in total dry weight (Table 2). Such results are in accordance with those reported by El-Gizawy et al. (2009), Idikut et al. (2009), A high N application rate leads to more rapid leaf area development, prolongs leaf life, improves leaf area duration after flowering and increase overall crop assimilation, thus contributing to increased yield (Balasubramaniyan and Palaniappan, 2001).

The results in Table 2 showed that $\mathrm{N}$ application resulted in significant increase in grain yield/fed. The higher $\mathrm{N}$ rate $(150 \mathrm{~kg} / \mathrm{fed}$.) was the most effective rate in increasing grain yield. Increasing $\mathrm{N}$ rates from 90 to $120 \mathrm{~kg} / \mathrm{fed}$. and from 120 to $150 \mathrm{~kg} / \mathrm{fed}$. increased grain yield/fed. by about $24.6 \%$ and $12.8 \%$ in the $1^{\text {st }}$ season, corresponding to $25.9 \%$ and $12.1 \%$ in the $2^{\text {nd }}$ season, respectively. Such results clarified that $\mathrm{N}$ is essential for cell division and elongation as well as root growth and dry matter of maize plants (Marschner, 1995). These results are in full agreement with those reported by AlNaggar et al. (2009), El-Gizawy (2009), Wasaya (2011) and Dawadi and Sah (2012). On the other hand, there is no significant difference in the yield of fed. after Egyptian clover between the nitrogen fertilization rate of 120 and $150 \mathrm{~kg} /$ fed. Therefore, it could be recommended to add up to $120 \mathrm{~kg} / \mathrm{fed}$. only to reduce costs and obtain economic yield increase.

Results in Fig. 2 indicated that regression analysis reveal the relations between the two variables, i. e., $\mathrm{N}$ rates $(\mathrm{x})$ and grain yield/fed $(\mathrm{y})$ indicated a linear relation as well as a highly significant $(\mathrm{P} \leq 0.01)$ correlation coefficient $(r=0.94)$ occurred during the first and second seasons. Besides, $\mathrm{R}^{2}$ (coefficient of determination), revealed that it was possible to account up to $94 \%$ of the variability in grain yield/fed. (y), to $\mathrm{N}$ rates $(\mathrm{kg} / \mathrm{fed}$.) during the first and second seasons, respectively. The relationship between $\mathrm{N}$ 
rates and grain yield/fed. was positively and followed the linear equation: of $\mathrm{Y}=9.7+0.35 \mathrm{x}$, representing a positive value of (b), during the first and second seasons, which mean yield increase against increase $\mathrm{N}$ rates (Fig. 2). Linear regression equation for $\mathrm{N}$ rates suggested that increase in one unit $(30 \mathrm{~kg} / \mathrm{fed}$.) lead to increased grain yield/fed. by 0.35 ton/fed. during the first and second seasons.

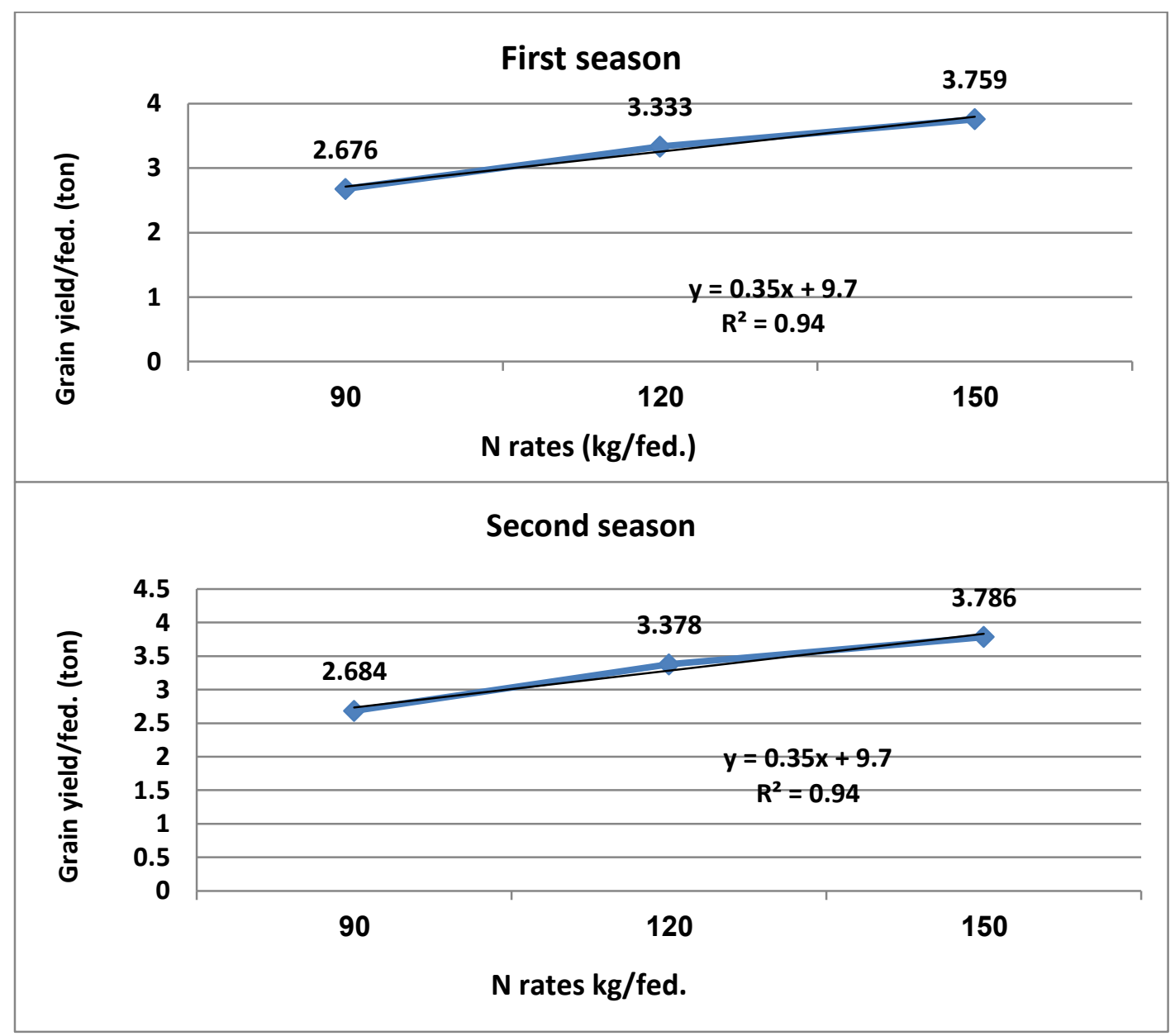

Fig. 2 Relationship between $\mathrm{N}$ rates and grain yield (ton/fed.) in 2015 and 2017 seasons.

Effect foliar application of micronutrients and $\mathrm{K}$ sulfate on growth and yield traits of maize S.C. 131

Foliar application technique is a particular way to supply macro and micro-nutrients which resulted in rapid absorption. Data presented in Table 2 revealed that the studied traits: total dry weights, leaf area index, plant height, grain yield per plant, grain yield/fed. and harvest index (H.I.) increased by applying micronutrients, $\mathrm{K}$ and their combination in both seasons. Table 2 showed that the highest values were obtained from spraying micronutrients and potassium together as compared to spraying both of them individually for the traits: total dry weight/plant (924.1 and 998.6 g), LAI (5.9 and 7.2), plant height $(225.4$ and $234.5 \mathrm{~cm})$, grain yield / plant (210.0 and $251.0 \mathrm{~g}$ ), grain yield/fed. (3.364 and 3.404 ton) and harvest index $(0.34$ and 0.24$)$ during the first and second seasons, respectively.

On contrast, the control treatment showed the lowest value for the total dry weight/plant (421.7 and
$943.2 \mathrm{~g})$, LAI (4.1 and 6.4), plant height (197.2 and $226.5 \mathrm{~cm}$ ), grain yield per plant (141.1 and $224.2 \mathrm{~g}$ ) grain yield/fed. (3.149and3.180 ton) and harvest index ( 0.30 and 0.28$)$ during the first and second seasons, respectively. These results showed the synergetic role of micronutrients in improving plant growth and other biochemical and physiological activities (Welch et al., 1991; El-Fouly el al., 1997\& 2011, Kassab et al., 2004 and Zeidan et al., 2010). Salem and El-Gizawy (2012) demonstrated that micronutrients fertilization using $\mathrm{Zn}+\mathrm{Mn}+\mathrm{Fe}$ treatment was the most effective treatment in all studied traits. Also, Safyan et al. (2012) found that microelements foliar spraying have a great role in increasing yield of grain corn in Iran, especially for iron+zinc and copper+ manganese. Similar results were found by Hythum et al, (2012) and Anees et al. (2016) who found that foliar spray of potassium and zinc; is a fertilizer use efficient technique for increasing the maize yield attributes and net income under rained conditions. 
Results in Fig. 3 indicate that regression analysis reveal the relations between the two variables, i. e., foliar application (x) and grain yield/fed. (y) indicated a linear relation as well as a highly significant $(\mathrm{P} \leq 0.01)$ correlation coefficient $(\mathrm{r}=0.99$ and 0.98$)$ occurred during the first and second seasons, respectively. Besides, $\mathrm{R}^{2}$ (coefficient of determination), revealed that it was possible to account up to $99 \%$ and 98 of the variability in yield of grain yield/fed. (y), to foliar application during the first and second seasons, respectively. The relationship between foliar application and grain yield/fed. was positively and followed the linear equation: of $\mathrm{Y}=3.0785+0.0709 \mathrm{x}$ and $\mathrm{Y}=0.0734+3.0995 \mathrm{x}$, representing a positive value of (b), during the first and second seasons, respectively, which mean yield increased against applied foliar application (Fig. 4).
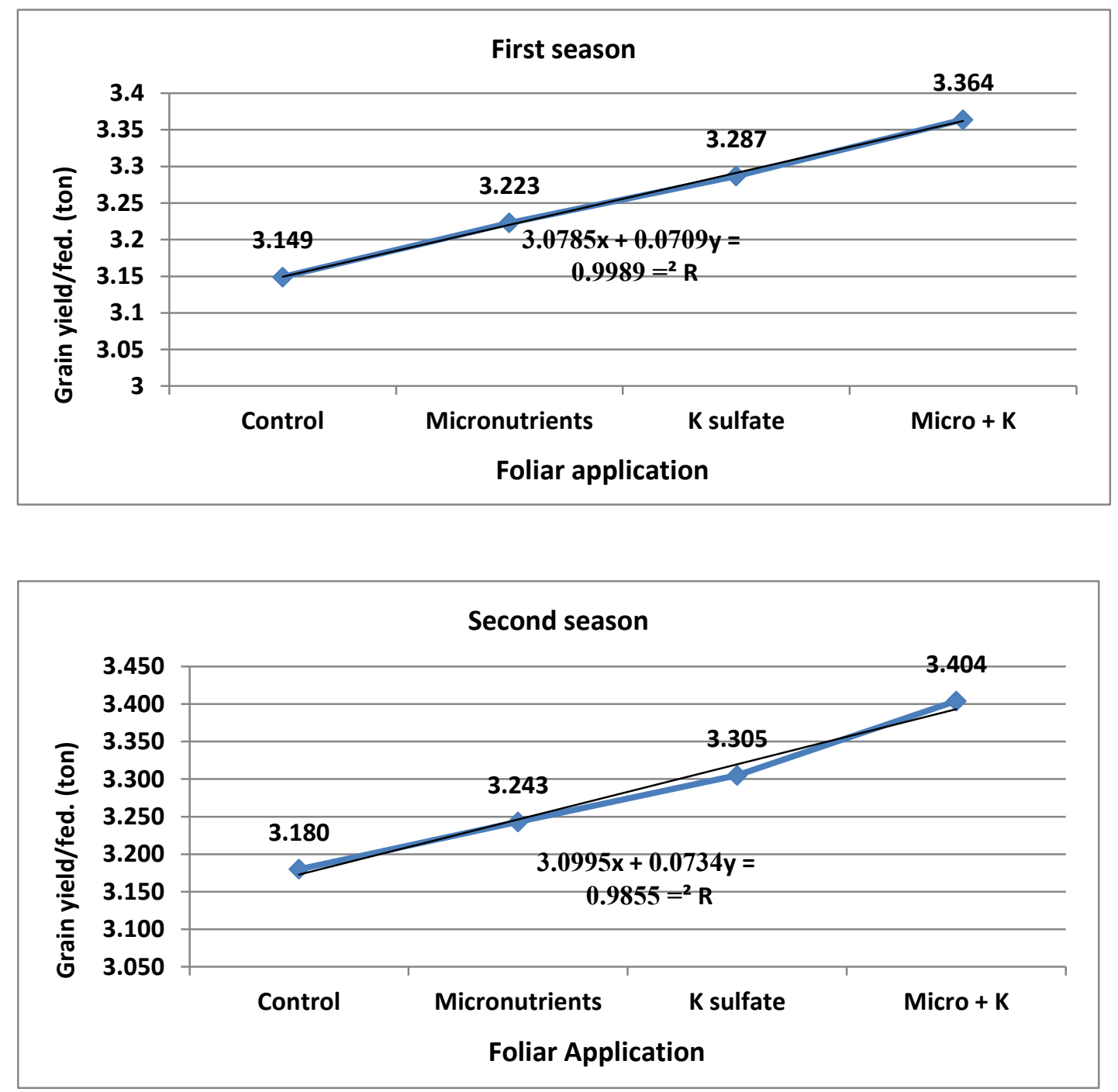

Fig. 3 Relationships between foliar application and grain yield/fed. (ton) in 2015 and2017 seasons.

Effect of nitrogen rates on some agronomic traits of maize preceded by wheat or Egyptian clover crop

Results presented in Table 3 showed significant interaction effects between preceding crops and $\mathrm{N}$ fertilizer on harvest index in both seasons. Results also indicate that maize grown after Egyptian clover and receiving $150 \mathrm{~kg} \mathrm{~N} / \mathrm{fed}$. recorded the maximum total dry weight/plant, LAI, plant height, grain yield plant and grain yield/fed. The lowest values of these parameters were obtained when maize was sown after wheat and fertilized by $90 \mathrm{~kg} \mathrm{~N} / \mathrm{fed}$. in both seasons. There are significant differences due to applying 120 $\mathrm{kg} \mathrm{N} /$ fed. to maize sown after Egyptian clover and 150 $\mathrm{kg} / \mathrm{fed}$. after wheat in both seasons (Table 3 ). It is very clear that the increase in $\mathrm{N}$ fertilizer when maize sown either after Egyptian clover or after wheat was significant in grain yield/fed., with less than or equal to half ton/fed. in both seasons. Data showed that by increasing $\mathrm{N}$ applied to maize planted after wheat the grain yield/feddan increased. Similar results were found by Shams (2000) and El-Gizawy (2009). Idikut et al. (2009) indicated that a preceding crop X N rate interaction had significant effect on seed yield during both years. 
Table 3. Effect of the interaction between preceding crop and nitrogen rate on some maize agronomic traits of maize cv single cross 131.

\begin{tabular}{|c|c|c|c|c|c|c|c|c|c|c|c|c|}
\hline \multirow[t]{2}{*}{$\begin{array}{l}\text { N rate } \\
\text { (kg/fed.) }\end{array}$} & \multicolumn{2}{|c|}{$\begin{array}{c}\text { Total dry } \\
\text { weight/plant } \\
(\mathrm{g})\end{array}$} & \multicolumn{2}{|c|}{$\begin{array}{l}\text { Leaf area } \\
\text { index }\end{array}$} & \multicolumn{2}{|c|}{$\begin{array}{l}\text { Plant height } \\
\text { (cm) }\end{array}$} & \multicolumn{2}{|c|}{$\begin{array}{c}\text { Grain } \\
\text { weight/plant } \\
\text { (g) }\end{array}$} & \multicolumn{2}{|c|}{$\begin{array}{l}\text { Grain } \\
\text { yield/fed. } \\
\text { (ton) }\end{array}$} & \multicolumn{2}{|c|}{$\begin{array}{c}\text { Harvest } \\
\text { index }(\%)\end{array}$} \\
\hline & 2015 & 2017 & 2015 & 2017 & 2015 & 2017 & 2015 & 2017 & 2015 & 2017 & 2015 & 2017 \\
\hline \multicolumn{13}{|l|}{ Wheat } \\
\hline 90 & 503.4 & 842.1 & 5.1 & 7.0 & 209.3 & 230.9 & 174.8 & 209.5 & 2.447 & 2.450 & 0.29 & 0.25 \\
\hline 120 & 582.3 & 916.3 & 5.0 & 6.7 & 219.7 & 229.1 & 188.3 & 233.5 & 3.113 & 3.195 & 0.30 & 0.26 \\
\hline 150 & 682.5 & 883.0 & 5.1 & 6.7 & 219.0 & 230.9 & 183.8 & 253.0 & 3.555 & 3.590 & 0.30 & 0.27 \\
\hline \multicolumn{13}{|c|}{ Egyptian clover } \\
\hline 90 & 761.9 & 1046.8 & 5.4 & 6.7 & 220.5 & 233.0 & 193.8 & 248.0 & 2.906 & 2.918 & 0.35 & 0.26 \\
\hline 120 & 951.0 & 1165.5 & 5.6 & 7.3 & 221.3 & 236.9 & 201.4 & 248.2 & 3.553 & 3.561 & 0.35 & 0.25 \\
\hline 150 & 1107.9 & 1064.9 & 5.8 & 7.2 & 221.2 & 234.8 & 208.0 & 255.2 & 3.963 & 3.983 & 0.36 & 0.25 \\
\hline LSD 5\% & 20.8 & 35.5 & 0.3 & 0.3 & 2.8 & 2.3 & 3.7 & 6.8 & 0.067 & 0.079 & $\mathrm{~ns}$ & ns \\
\hline
\end{tabular}

ns; not significant

Effect of the interaction between preceding crop and foliar application of micronutrients and $\mathrm{K}$ sulfate on some agronomic traits of maize

The interaction effects of preceding crops and foliar application of micronutrients and potassium sulphate were significant on: total dry weight, LAI, plant height, grain yield per plant and per feddan in both seasons, while harvest index was not significantly affected by this interaction, indicating that different foliar applications combinations behaved differently under different preceding crops for maize(Tables 4). Results also indicated that maize grown after Egyptian clover and Micronutrients $+\mathrm{K}$ sulfate foliar applications recorded the maximum values of all traits under studied in both seasons. The lowest values of these parameters were obtained with sowing maize after wheat in both seasons. Salem and El-Gizawy (2012) revealed that micronutrient fertilization using $\mathrm{Zn}+\mathrm{Mn}+\mathrm{Fe}$ treatment was the most effective treatment in recording the highest values of all studied traits of maize.

Table 4. Effect of the interaction between preceding crop and foliar applications of micronutrients and K sulfate on some agronomic maize traits

\begin{tabular}{|c|c|c|c|c|c|c|c|c|c|c|c|c|}
\hline \multirow[t]{2}{*}{$\begin{array}{l}\text { Foliar } \\
\text { application }\end{array}$} & \multicolumn{2}{|c|}{$\begin{array}{c}\text { Total dry } \\
\text { weight/plant (g) }\end{array}$} & \multicolumn{2}{|c|}{$\begin{array}{l}\text { Leaf area } \\
\text { index }\end{array}$} & \multicolumn{2}{|c|}{$\begin{array}{l}\text { Plant height } \\
\text { (cm) }\end{array}$} & \multicolumn{2}{|c|}{$\begin{array}{c}\text { Grain } \\
\text { yield/Plant (g) }\end{array}$} & \multicolumn{2}{|c|}{$\begin{array}{c}\text { Grain } \\
\text { yield/fed. } \\
\text { (ton) }\end{array}$} & \multicolumn{2}{|c|}{$\begin{array}{c}\text { Harvest index } \\
(\%)\end{array}$} \\
\hline & 2015 & 2017 & 2015 & 2017 & 2015 & 2017 & 2015 & 2017 & 2015 & 2017 & 2015 & 2017 \\
\hline \multicolumn{13}{|l|}{ After Wheat } \\
\hline Control & 346.8 & 861.5 & 4.0 & 6.1 & 196.2 & 226.0 & 133.8 & 210.0 & 2.936 & 2.987 & 0.28 & 0.26 \\
\hline Micronutrients & 615.3 & 862.9 & 5.4 & 6.9 & 224.4 & 230.4 & 197.7 & 235.1 & 3.004 & 3.046 & 0.30 & 0.26 \\
\hline K sulfate & 686.3 & 863.6 & 5.3 & 7.1 & 221.2 & 233.4 & 197.8 & 235.9 & 3.066 & 3.097 & 0.30 & 0.25 \\
\hline Micro + K & 709.3 & 934.0 & 5.5 & 7.1 & 222.0 & 231.3 & 199.8 & 247.0 & 3.146 & 3.184 & 0.31 & 0.25 \\
\hline \multicolumn{13}{|c|}{ After Egyptian clover } \\
\hline Control & 496.7 & 1025.0 & 4.3 & 6.6 & 198.1 & 227.0 & 148.4 & 238.4 & 3.362 & 3.372 & 0.31 & 0.29 \\
\hline Micronutrients & 1030.9 & 1187.2 & 5.7 & 7.2 & 227.3 & 236.1 & 220.1 & 254.4 & 3.442 & 3.441 & 0.36 & 0.26 \\
\hline K sulfate & 1094.7 & 1094.2 & 6.1 & 7.1 & 228.3 & 238.9 & 215.7 & 253.9 & 3.508 & 3.512 & 0.37 & 0.24 \\
\hline Micro + K & 1138.9 & 1063.2 & 6.2 & 7.4 & 228.9 & 237.7 & 220.2 & 255.0 & 3.583 & 3.623 & 0.37 & 0.23 \\
\hline LSD 5\% & 29.0 & 51.0 & 0.2 & 0.2 & 2.6 & 2.0 & 4.0 & 6.0 & ns & ns & 0.10 & 0.03 \\
\hline
\end{tabular}

Effect of the interaction between nitrogen rates and foliar application of micronutrients and $\mathrm{K}$ sulfate on some agronomic traits of maize

Results presented in Table 5 indicated that there were no significant interaction effects between $\mathrm{N}$ fertilizer and foliar of nutrients application on harvest index in both seasons. It is noted that with applying micronutrients and potassium, the values of the traits increased with increasing nitrogen rate compared with the control in both seasons. This indicated that foliar feeding can increase the efficiency of the use of added nitrogen. Therefore, there is no significant difference between nitrogen fertilizer rate of 120 or $150 \mathrm{~kg} \mathrm{~N} / \mathrm{fed}$. and the addition of foliar application of micronutrients and potassium in both seasons. Foliar application of micro and potassium with $150 \mathrm{~kg} \mathrm{~N} / \mathrm{fed}$. gave the highest grain yield/plant and grain yield/fed. in the first and second seasons, total dry weight/plant, LAI and plant height in first season. Also, the results in Table 5 showed that the interaction between foliar application and the addition of $90 \mathrm{~kg} \mathrm{~N} / \mathrm{fed}$. gave the lowest values for total dry weight/plant, LAI, plant height, grain yield/plant and grain yield/fed. in both seasons. 
Table 5. Effect of the interaction between nitrogen rate and foliar application of micronutrients and K sulfate on some agronomic traits of maize.

\begin{tabular}{|c|c|c|c|c|c|c|c|c|c|c|c|c|c|}
\hline \multirow{2}{*}{$\begin{array}{c}\text { N rate } \\
\text { (kg/fed.) }\end{array}$} & \multirow{2}{*}{$\begin{array}{c}\text { Foliar } \\
\text { app. }\end{array}$} & \multicolumn{2}{|c|}{$\begin{array}{c}\text { Total dry } \\
\text { weight/plant (g) }\end{array}$} & \multicolumn{2}{|c|}{$\begin{array}{c}\begin{array}{c}\text { Leaf area } \\
\text { index }\end{array} \\
\end{array}$} & \multicolumn{2}{|c|}{$\begin{array}{c}\text { Plant height } \\
(\mathrm{cm})\end{array}$} & \multicolumn{2}{|c|}{$\begin{array}{c}\text { Grain } \\
\text { weight/plant (g) }\end{array}$} & \multicolumn{2}{|c|}{$\begin{array}{c}\text { Grain yield } \\
\text { (ton/fed.) }\end{array}$} & \multicolumn{2}{|c|}{$\begin{array}{c}\text { Harvest } \\
\text { index }(\%)\end{array}$} \\
\hline & & 2015 & 2017 & 2015 & 2017 & 2015 & 2017 & 2015 & 2017 & 2015 & 2017 & 2015 & 2017 \\
\hline \multirow{4}{*}{90} & Control & 352.5 & 878.4 & 4.2 & 6.3 & 194.0 & 226.7 & 128.3 & 213.3 & 2.595 & 2.585 & 0.28 & 0.27 \\
\hline & Micro. & 668.7 & 1017.6 & 5.5 & 7.0 & 221.2 & 233.4 & 200.5 & 230.8 & 2.641 & 2.651 & 0.33 & 0.26 \\
\hline & $\begin{array}{c}\text { K } \\
\text { sulfate }\end{array}$ & 719.5 & 943.7 & 5.7 & 7.1 & 221.3 & 234.3 & 203.5 & 233.5 & 2.702 & 2.716 & 0.33 & 0.24 \\
\hline & $\begin{array}{c}\text { Micro + } \\
\text { K }\end{array}$ & 790.0 & 938.1 & 5.7 & 7.1 & 222.7 & 233.4 & 205.0 & 237.3 & 2.766 & 2.784 & 0.34 & 0.24 \\
\hline \multirow{4}{*}{120} & Control & 407.5 & 998.2 & 4.2 & 6.5 & 198.8 & 226.5 & 149.1 & 226.3 & 3.210 & 3.269 & 0.30 & 0.28 \\
\hline & Micro. & 791.6 & 1027.2 & 5.6 & 7.1 & 227.8 & 232.6 & 214.1 & 241.8 & 3.304 & 3.346 & 0.33 & 0.25 \\
\hline & $\begin{array}{c}\mathbf{K} \\
\text { sulfate }\end{array}$ & 926.9 & 1047.0 & 5.6 & 6.8 & 227.7 & 239.0 & 206.8 & 243.8 & 3.375 & 3.397 & 0.33 & 0.25 \\
\hline & $\begin{array}{c}\text { Micro + } \\
\text { K }\end{array}$ & 940.6 & 1091.1 & 5.8 & 7.6 & 227.7 & 233.9 & 209.4 & 251.3 & 3.443 & 3.500 & 0.34 & 0.24 \\
\hline \multirow{4}{*}{150} & Control & 505.2 & 953.2 & 4.0 & 6.3 & 198.7 & 226.4 & 145.9 & 233.0 & 3.644 & 3.684 & 0.30 & 0.28 \\
\hline & Micro. & 1009.1 & 1030.3 & 5.8 & 7.0 & 228.3 & 233.6 & 212.1 & 261.7 & 3.724 & 3.733 & 0.33 & 0.27 \\
\hline & $\begin{array}{c}\text { K } \\
\text { sulfate }\end{array}$ & 1025.0 & 946.1 & 5.9 & 7.4 & 225.3 & 235.2 & 209.9 & 257.3 & 3.784 & 3.801 & 0.34 & 0.25 \\
\hline & $\begin{array}{c}\text { Micro + } \\
\text { K }\end{array}$ & 1041.7 & 966.4 & 6.1 & 7.0 & 226.0 & 236.3 & 215.6 & 264.3 & 3.883 & 3.927 & 0.34 & 0.23 \\
\hline LSD 5\% & & 35.5 & 62.5 & 0.3 & 0.2 & 3.2 & 2.5 & 4.8 & 2.1 & 0.123 & 0.111 & ns & ns \\
\hline
\end{tabular}

Effect of the interaction between nitrogen rates and foliar applications of micronutrients and $\mathrm{K}$ sulfate on some agronomic traits of maize preceded by wheat or Egyptian clover

There was a second order interaction which involved the three factors of this study (Table 6).
Sowing maize after Egyptian clover or wheat and receiving $\mathrm{N}$ rates as well as foliar nutrients gave significant difference in total dry weight, LAI and grain yield/fed. in both seasons (Table 6).

Table 6. Effect of the interaction between nitrogen rate and foliar application of micronutrients and K sulfate on some agronomic traits of maize preceded by wheat or Egyptian clover.

\begin{tabular}{|c|c|c|c|c|c|c|c|c|c|c|c|c|c|}
\hline \multirow[t]{2}{*}{$\begin{array}{c}\text { N rate } \\
\text { (kg/fed.) }\end{array}$} & \multirow[t]{2}{*}{ Foliar app. } & \multicolumn{2}{|c|}{$\begin{array}{c}\text { Total dry } \\
\text { weight/plant (g) }\end{array}$} & \multicolumn{2}{|c|}{$\begin{array}{l}\text { Leaf area } \\
\text { index }\end{array}$} & \multicolumn{2}{|c|}{$\begin{array}{l}\text { Plant height } \\
\text { (cm) }\end{array}$} & \multicolumn{2}{|c|}{$\begin{array}{c}\text { Grain } \\
\text { weight/plant } \\
\text { (g) }\end{array}$} & \multicolumn{2}{|c|}{$\begin{array}{c}\text { Grain } \\
\text { yield/fed. } \\
\text { (ton) }\end{array}$} & \multicolumn{2}{|c|}{$\begin{array}{l}\text { Harvest } \\
\text { index }(\%)\end{array}$} \\
\hline & & 2015 & 2017 & 2015 & 2017 & 2015 & 2017 & 2015 & 2017 & 2015 & 2017 & 2015 & 2017 \\
\hline \multicolumn{14}{|c|}{ After Wheat } \\
\hline \multirow{4}{*}{90} & Control & 310.0 & 689.5 & 4.6 & 6.0 & 191.7 & 228.8 & 120.6 & 186.7 & 2.375 & 2.375 & 0.27 & 0.25 \\
\hline & Micronutrients & 478.7 & 823.3 & 5.5 & 7.2 & 215.3 & 231.0 & 189.7 & 212.7 & 2.417 & 2.427 & 0.29 & 0.25 \\
\hline & K sulfate & 575.0 & 930.5 & 5.1 & 7.4 & 214.0 & 233.7 & 196.3 & 214.0 & 2.464 & 2.464 & 0.30 & 0.24 \\
\hline & Micro + K & 650.0 & 925.1 & 5.3 & 7.4 & 216.0 & 230.0 & 192.7 & 224.7 & 2.529 & 2.534 & 0.31 & 0.25 \\
\hline \multirow{5}{*}{120} & Control & 320.0 & 964.0 & 4.0 & 6.1 & 196.7 & 223.3 & 142.5 & 212.7 & 3.003 & 3.103 & 0.28 & 0.26 \\
\hline & Micronutrients & 579.3 & 857.2 & 5.3 & 6.8 & 228.7 & 228.6 & 206.9 & 232.7 & 3.080 & 3.164 & 0.31 & 0.25 \\
\hline & K sulfate & 728.8 & 856.8 & 5.1 & 6.4 & 226.7 & 234.7 & 199.3 & 237.0 & 3.143 & 3.211 & 0.30 & 0.26 \\
\hline & Micro + K & 701.1 & 987.4 & 5.4 & 7.5 & 226.7 & 230.0 & 204.5 & 251.7 & 3.225 & 3.304 & 0.30 & 0.25 \\
\hline & Control & 410.3 & 931.0 & 3.3 & 6.3 & 200.3 & 226.0 & 138.3 & 230.7 & 3.430 & 3.481 & 0.28 & 0.29 \\
\hline \multirow{3}{*}{150} & Micronutrients & 788.1 & 908.1 & 5.5 & 6.6 & 229.3 & 231.5 & 196.7 & 260.0 & 3.514 & 3.547 & 0.30 & 0.28 \\
\hline & K sulfate & 755.0 & 803.6 & 5.7 & 7.5 & 223.0 & 232.0 & 197.7 & 256.7 & 3.592 & 3.617 & 0.31 & 0.25 \\
\hline & Micro + K & 776.7 & 889.4 & 5.8 & 6.4 & 223.3 & 234.0 & 202.3 & 264.7 & 3.682 & 3.715 & 0.31 & 0.24 \\
\hline \multicolumn{14}{|c|}{ After Egyptian clover } \\
\hline \multirow{4}{*}{90} & Control & 395.0 & 1067.2 & 3.9 & 6.6 & 196.3 & 224.6 & 136.0 & 240.0 & 2.814 & 2.795 & 0.29 & 0.29 \\
\hline & Micronutrients & 858.7 & 1211.9 & 5.4 & 6.8 & 227.7 & 235.8 & 211.3 & 249.0 & 2.865 & 2.875 & 0.36 & 0.27 \\
\hline & K sulfate & 864.0 & 956.8 & 6.2 & 6.8 & 228.7 & 235.0 & 210.7 & 253.0 & 2.940 & 2.968 & 0.36 & 0.24 \\
\hline & Micro + K & 930.0 & 951.2 & 6.0 & 6.8 & 229.3 & 236.7 & 217.3 & 250.0 & 3.004 & 3.033 & 0.36 & 0.23 \\
\hline \multirow{4}{*}{120} & Control & 495.0 & 1032.5 & 4.3 & 6.8 & 201.0 & 229.7 & 155.7 & 240.0 & 3.416 & 3.435 & 0.32 & 0.29 \\
\hline & Micronutrients & 1004.0 & 1197.2 & 5.8 & 7.3 & 227.0 & 236.7 & 221.3 & 251.0 & 3.528 & 3.528 & 0.36 & 0.24 \\
\hline & K sulfate & 1125.0 & 1237.3 & 6.1 & 7.3 & 228.7 & 243.3 & 214.3 & 250.7 & 3.607 & 3.584 & 0.36 & 0.23 \\
\hline & Micro + K & 1180.0 & 1194.9 & 6.2 & 7.7 & 228.7 & 237.8 & 214.3 & 251.0 & 3.661 & 3.696 & 0.37 & 0.22 \\
\hline \multirow{4}{*}{150} & Control & 600.0 & 975.3 & 4.6 & 6.4 & 197.0 & 226.7 & 153.5 & 235.3 & 3.857 & 3.887 & 0.32 & 0.27 \\
\hline & Micronutrients & 1230.0 & 1152.4 & 6.0 & 7.5 & 227.3 & 235.7 & 227.6 & 263.3 & 3.934 & 3.920 & 0.36 & 0.26 \\
\hline & K sulfate & 1295.0 & 1088.5 & 6.1 & 7.4 & 227.7 & 238.3 & 222.1 & 258.0 & 3.976 & 3.985 & 0.37 & 0.24 \\
\hline & Micro + K & 1306.7 & 1043.4 & 6.5 & 7.7 & 228.7 & 238.5 & 228.9 & 264.0 & 4.083 & 4.139 & 0.37 & 0.23 \\
\hline LSD 5\% & & 50.2 & 88.4 & 0.4 & 0.3 & ns & $\mathrm{ns}$ & ns & $\mathrm{ns}$ & 0.174 & 0.113 & ns & ns \\
\hline
\end{tabular}

ns; not significant

The effects of this interaction were insignificant on plant height, grain yield/plant and harvest index in both seasons. Maize plants grown after Egyptian clover and receiving $150 \mathrm{~kg} \mathrm{~N} / \mathrm{fed}$. with the applied 
micronutrients and $\mathrm{k}$ foliar gave the highest grain yield/fed. (4.083 and 4.139 ton).However, no significant difference between 120 and $150 \mathrm{~kg} \mathrm{~N} / \mathrm{fed}$. in both seasons. The lowest values of grain yield/fed. was shown when maize was grown after wheat and receiving $90 \mathrm{~kg} \mathrm{~N} / \mathrm{fed}$. with foliar application of micro and $\mathrm{k}$ elements in both seasons.

\section{Conclusion}

Based on the findings of this study, it could be concluded that under conditions of the current experiment, maize grown after Egyptian clover and receiving $120 \mathrm{~kg} \mathrm{~N} / \mathrm{fed}$. combined with foliar application of micronutrients and $\mathrm{K}$ are recommended for maize production. On the other hand, maize grown after wheat and receiving $150 \mathrm{~kg} \mathrm{~N} / \mathrm{fed}$. at foliar application of micronutrients and $\mathrm{K}$ are recommended for maize production. Regression analysis reveal the relation between the two variables, i. e., preceding crop (x) and grain yield/fed. (y) there was a linear relation, and, highly significant $(\mathrm{P} \leq 0.01)$ correlation coefficient $(\mathrm{r}=1)$ during the first and second seasons. Linear regression equation for $\mathrm{N}$ rates suggested that increase in one unit (30 kg/fed.) led to increased grain yield/fed. by 0.35 ton/fed. during the first and second seasons.

\section{References}

Abd El-All, A.M. (2002). Effect of preceding crops, organic and mineral nitrogen and plant density on productivity of maize plant. J. Agric. Sci., Mansora Univ., 27(12): 8093-8105.

Al-Naggar, A. M. M.; Atta, M. M. M. and Amein, M. M. (2009). Maize genotypic differences in nitrogen use efficiency under low-soil $\mathrm{N}$ conditions. Egypt. J. Appl. Sci., 24 (3B): 528 546.

Anees, M.A.; Ali, A.; Shakoor, U.; Ahmed, F.; Hasanin, Z. and Hussain, A. (2016). Foliar applied potassium and zinc enhances growth and yield performance of maize under rainfed conditions. Int. J. Agric. Biol., 18(5): 1025-1032.

Aslam, M.; Zamir, M. S. I.; Afzal, I.; Yaseen, M.; Mubeen, M. and Shoaib, A. (2013).Drought stress, its effect on maize production and development of drought tolerance through potassium application. Cercetări Agronomic in Moldova, 2 (154): 99-114.

Badr, S. K. A. (1999). Effect of some preceding winter crops and application time of micronutrients on growth, yield and yield components of yellow maize in sandy soil. Minufiya J. Agric. Res., 24(3): 895-909.

Balasubramaniyan, P.; and Palaniappan, S. P. (2001). Principles and Practices of Agronomy. 185 p. Agrobios, Jodhpur, India.
Black, C. A. (1965). Methods of Soil Analysis. Amer. Soc. of Agronomy, Inc. Pub. Madison, Wisconsin, USA.

Clipson, N. J. W.; Edwards, S. J.; Hall, J. F.; Leach, C. K.; Rayns, F. W. and Weston, G.D. (1994). Crop Productivity. Published on Behalf of: Open Univ. and Univ. Green wish (Formerly Thames Polytechnic), Avery Hill Road, Eltham, London SE92HB, 5.

Dawadi, D. R. and Sah, S. K. (2012). Growth and yield of hybrid maize (Zea mays L.) in relation to planting density and nitrogen levels during winter season in Nepal. Trop. Agri. Res., 23(3): 218-227.

El-Akabawy, M. A.; Mahdy, M. A.; Badr, M. M. A. and Nadia, O. Monged (2001).Effect of biofertilizers and micronutrients on the yield and mineral composition of maize plants at different levels of nitrogen. Egypt. J. Appl. Sci., 16(8): 332344.

El-Douby, K. A. (2002). Effect of preceding crops and bio-mineral fertilizer on growth and yield of maize. Annals Agric. Sci., Moshtohor, 40(1): 2737.

El-Fouly, M. M.; Mobarak, Z. M. and Salama, Z. A. (1997).Comparative study on the effect of chelated multi micronutrient compounds on the growth and nutrient uptake in some plants. Egypt J. Physiol. Sci., 21: 447-458.

El-Fouly, M. M.; Mobarak, Z. M. and Salama, Z. A. (2011). Micronutrients (Fe, $\mathrm{Mn}, \mathrm{Zn}$ ) foliar spray for increasing salinity tolerance in wheat (Triticum aestivum L.). African J. Plant Sci.,5(5): 314-322.

El-Gizawy, N. Kh. B. (2009). Effects of nitrogen rate and plant density on agronomic nitrogen efficiency and maize yields following wheat and faba bean. American-Eurasian J. Agric. \& Environ. Sci., 5(3): 378-386.

El-Gizawy, N. Kh. B. (2000). Response of maize (Zea mays L.) to nitrogen and manganese fertilization. Ph.D. Thesis, Fac. Agric. Moshtohor, Benha Univ. (cited from Hythum et al. 2012)

FAO (2016).FAOSTAT-Agriculture Database.FAO, Rome,http://faostat.fao.org/.

Freed, R D. (1991). MSTATC Microcomputer Statistical Program.Michigan State Univ. East Lansing, Michigan, USA.

Gomez, K. A. and Gomez, A. A. (1983). Statistical Procedures for Agricultural Research, John Willey and Sons, Inc. New York. (Cited from Hythum et al. 2012)

Hythum M. S. and El-Gizawy, N. Kh. B. (2012). Importance of micronutrients and its application methods for improving maize (Zea mays L.)yield grown in clayey soil. American-Eurasian J. Agric. \& Environ. Sci., 12 (7): 954-959.)

Idikut, L.; Tiryaki, I.; Tosun, S. and Celep, H. (2009). Nitrogen rate and previous crop effects on some agronomic traits of two corn (Zea mays L.) 
cultivars Maverik and Bora. African Journal of Biotechnology, 8 (19): 4958-4963.

Kabata-Pendias, A. and Pendias, H. (1999). Biogeochemistry of Trace Elements. PWN, Warsaw,Poland. (cited from Hythum et al. 2012).

Kandil, E. E. E. (2013). Response of Some Maize Hybrids (Zea mays L.) to Different Levels of Nitrogenous Fertilization. J. Appl. Sci. Res., 9(3): 1902-1908.

Kassab, O. M.; Zeing, H. A. E. and Ibrahim, M. M. (2004). Effect of water deficit and micronutrients foliar application on the productivity of wheat plants. Minufiya J. Agric. Res., 29: 925-932.

Khalil, H.; El-Tabbakh, S. Sh.; El-Ganbeehy, M. M. and Toaima, S. E. (2001). Maize response to preceding winter crops and phosphorus levels. J. Agric., Sci., Mansoura Univ., 26(1): 105-115.

Khan, N.W.; Ijaz, N. K. and Khan, A. (2012). Integration of nitrogen fertilizer and herbicides for efficient weed management in maize crop. Sarhad J. Agric., 28(3): 457-463.

Marschner, H. (1995). Mineral Nutrition of Higher Plants. $2^{\text {nd }}$ ed. New York: Academic Press, Harcourt Brace Jovanovich, Published, 674 p.

Onasanya, R. O.; Aiyelari, O. P.; Onasanya, A.; Oikeh, S.; Nwilene, F. E. and Oyelakin, O.O. (2009). Growth and yield response of maize (Zea mays L.) to different rates of nitrogen and phosphorus fertilizers in southern Nigeria. World J. Agric. Sci., 5 (4): 400-407.

Rego, T. J.; Sahrawat, K. L.; Wani, S. P. and Pardhasaradhi, G. (2007). Widespread deficiencies of sulfur, boron and zinc in Indian semi-arid tropical soils: on-farm crop. J. Plant Nutr., 30: 1569-1583.

Safyan, N.; Naderidarbaghshahi, M. R.; and Bahari, B. (2012). The effect of microelements spraying on growth, qualitative and quantitative grain corn in Iran. Intl. Res. J. Appl. Basic. Sci., 3(S): 2780-2784.

Salem, H. M. and El-Gizawy; N. Kh. B. (2012). Importance of micronutrients and its application methods for improving maize (Zea mays L.) yield grown in clayey soil. American-Eurasian J. Agric. \& Environ. Sci., 12 (7): 954-959.

Shams, S. A. A. (2000). Effect of some preceding winter crops, nitrogen levels and zinc foliar application on grain yield of maize (Zea mays L.). Annals Agric. Sci., Moshtohor, 38(1): 47-63.

Toaima, S. E. A. and Saleh, S. A. (2003). Yield and yield components of maize and sunflower as affected by preceding crops and N-fertilizer level. J. Agric. Sci. Mansoura Univ., 28(4):2467-2476.

Varvel, G. E. and Peterson, T. A. (1990).Residual soil nitrogen as affected by continuous two-year and four-year crop rotation systems. Agron. J., 82: 958-962.

Wasaya, A.; Tahir M.; Manaf A.; Ahmed M.; Kaleem S. and Ahmad I. (2011). Improving maize productivity through tillage and nitrogen management. African Journal of Biotechnology Vol 10, No 82: 19005-19010.

Wei, S.; Wang, X.; Shi, D.; Li, Y.; Zhang, J.; Liu, P., Zhao, B. and Dong, S. (2016). The mechanisms of low nitrogen induced weakened photosynthesis in summer maize (Zea mays L.) under field conditions. Plant Physiology and Biochemistry 105: 118-128.

Welch, R. M.; Allaway, W. H.; House, W. A. and Kubota, I. (1991). Geographic distribution of trace element problems. In: Micronutrients in Agriculture. J. Mortvedt, Soil Sci. Soc. Am Inc. Madison, WI. (cited from Hythum et al. 2012)

Zeidan, M. S.; Mohamed, M. F. and Hamouda, H. A. (2010). Effect of foliar fertilization of Fe, Mn and $\mathrm{Zn}$ on wheat yield and quality in low sandy soils fertility. World J. Agric. Sci., 6 (6): 696-699.

$$
\begin{aligned}
& \text { تأثير مستويات النيتروجين والرش الورقى بسلفات البوتاسيوم والعناصر الصغرى المغذية على نمو بور }
\end{aligned}
$$

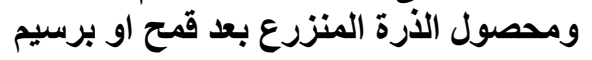

$$
\begin{aligned}
& \text { المنولى عبداله المنولى1, سيد احمد سفينها, فؤاد السيد عبدالة2, رمضان خليفه محمد2 و سارة سيد على الصاوى2 }
\end{aligned}
$$

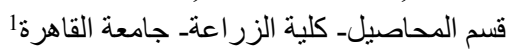

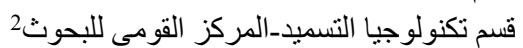


القطاعات المذشقة مرتين فى ثلاث مكررات. اظهرت النتاتج: ان نباتات الذرة المنزر ع بعد البر سيم الدصرى اعطت اعلى القيم لكل من مدصول حبوب النبات الواحد (201.1-250.4 جم), مدصول الحبوب للفدان (3.472-3.487 طن) بالاضافة الى دليل الحصاد

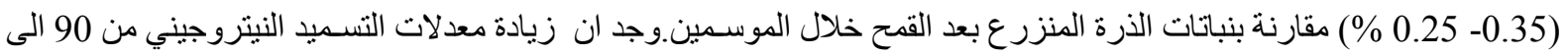

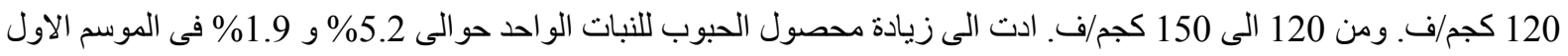

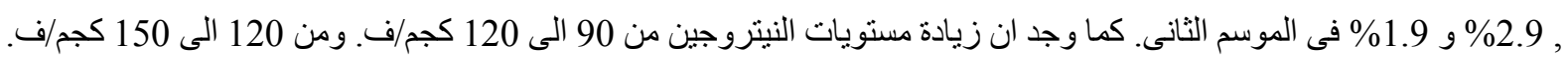

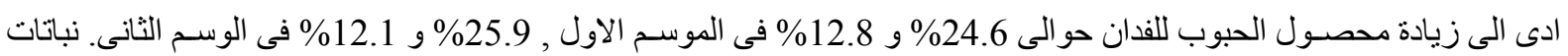

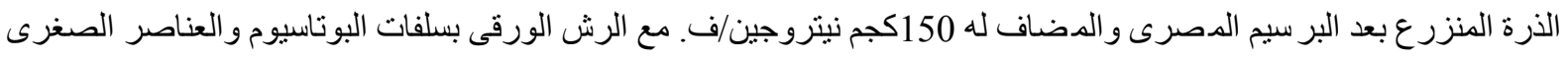

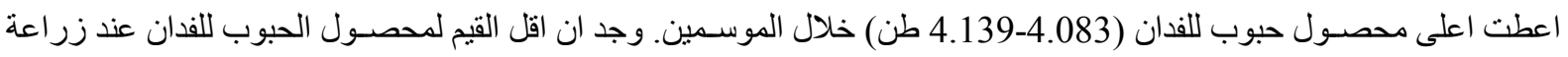
نباتات الذرة بعد القمح و المضاف له 90 كجم نيتروجين/ف. مع الرش الورقى بسلفات البوتاسيوم و العناصر الصغرى خلال الموسمين.

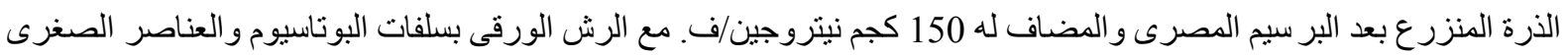

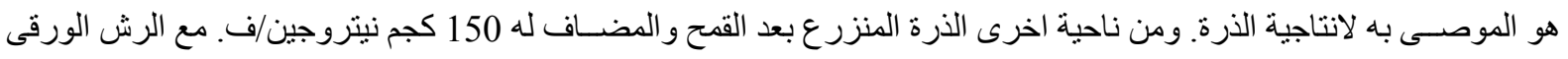

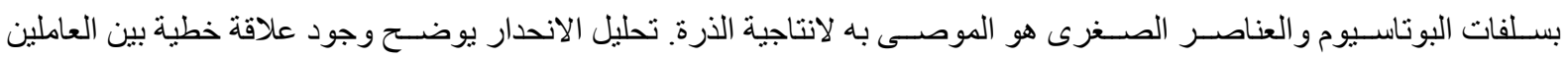

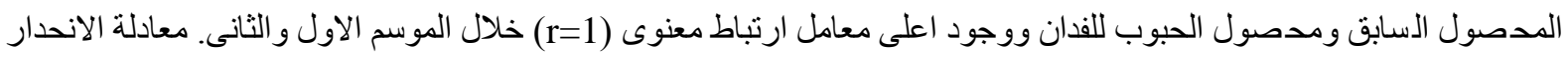

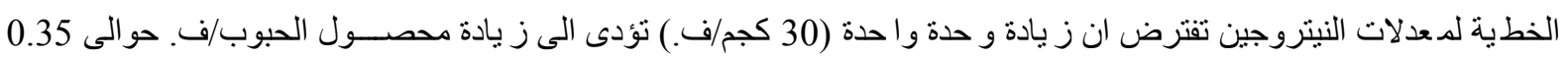
طن/ف. خلال الموسم الاول و الثانى. 